\title{
METAPHYSICAL OR DIFFERENTIAL: FITZGERALD'S THE GREAT GATSBY UNDER DERRIDEAN CONCEPT OF LOVE
}

\author{
Sayed Mohammad Anoosheh, Yazd University, Iran \\ Muhammad Hussein Oroskhan, Shiraz University, Iran
}

\begin{abstract}
Jacques Derrida revolutionized Western Philosophy by reconsidering the previous ideas from a new perspective. In his view, human subjectivity is explained within the system of language and the meaning is conveyed through the concept of differánce. As such, he imparts the notion that nothing ever exists outside the text, yet the text is filled with innumerable meanings, not a specific one. The net of his deconstructive thinking cast vast enough to devote close critical attention to any previously regarded metaphysical idea like love. Transcendental or metaphysical love is a shorn of meaning in the Derridean notion of deconstruction. For Derrida, love as a communicable sign is confined to the rules of iterability which proves the free flow of signifiers. In this regard, Fitzgerald's The Great Gatsby as one of the most critically studied works in America is recruited to examine the Derridean deconstructive notion of love. Gatsby is exclusively focused on seeking Daisy's transcendental love even at the expense of repeating the past. Nonetheless, the evanescent fluidity of the notion of love totally ruins Gatsby's chance of ever achieving Daisy's love. Accordingly, Gatsby's ultimate failure is expected for the reason that an "absolute moment" is never devoid of any trace of past or future time. Thus, The Great Gatsby attends to why the notion of love defies any metaphysical or transcendental status and instead it has differential and deferral meaning.
\end{abstract}

Keywords: The Great Gatsby, love, deconstruction, difference, inerrability. 


\section{Introduction}

The beginning of the twentieth century ushered a circle of changes in American history. F. Scott Fitzgerald (1896-1940) tried to aptly encapsulate these changes in his works. His best attempt succeeds most probably in The Great Gatsby (1925) which is "one of two American books loved by both literary critics and a wide, general audience" (Keshmiri, 2016, p. 1296). More prominent, however, is the way Fitzgerald attempts to dissect the complexities of his time in his masterpiece. With Fitzgerald's critical eye, The Great Gatsby becomes a microcosm reflecting the 1920's American society. Fitzgerald's primary aim was to write "something newsomething extraordinary and beautiful and simple and intricately patterned" (Fitzgerald, 1978 , p. 14), yet, the novel describes the shattering American society by revealing certain puzzling features beneath the surface of this society:

The tragedy of Gatsby as that of an individual and of a civilization would clearly depict the devastation of the dream (or shall we say the fantasy?) the American man was carrying along since he started building up the New World; the shattered image of success, idealism, and glory in a meretricious life (Ghasemi and Tiur, 2009, p. 35).

Thomas Streissguth in The Roaring Twenties (2007) draws critical attention to the underlying reason beyond such sweeping changes in the 1920's American Society by attesting to the fact that it is for the first time in the American history that urban society is shaped with more than half of the population living in cities (xi). Accordingly, Fitzgerald's central puzzle is to portray not specifically the transformation of American society into an urban society but more exquisitely the aftermath of such transformation on individuals' lives. To this end, Fitzgerald recruits all his efforts to study his age through The Great Gatsby. In this regard, Cleanth Brooks (1973) asserts that:

Historically, the 1920s were not only an age of disillusionment and frenetic excitement; they were also an age of vital creativity and intellectual development.... But the world in which he [Fitzgerald] did immerse himself he reported as faithfully and came to judge as honestly, as he could (p. 2284).

Fitzgerald's recording of American society in The Great Gatsby narrates to us the constitution of a new society which seems to end in failure as none of its ends is achieved. Perhaps, "Gatsby and his myth is an emblem of the irony of American history and the corruption of the American dream" (Ghasemi and Tiur, 2009, p. 119). Consisted of the narration of America society, Fitzgerald unfolds the unfortunate path of its failure, the dream of not arriving at the desirable society. Hence, a discussion of the failure of the American dream is permeated through The Great Gatsby. An inevitable consequence of such perspective is that The Great Gatsby has become "the embodiment of the fluid polarities of the American experience: success and failure, illusion and disillusion, dream and nightmare"(Ghasemi and Tiur, 2009, p. 119). Clarification of such woven concepts in The Great Gatsby needs a new method of study which can highlight some new aspects of this masterpiece.

The Great Gatsby is a work full of opposite poles and the search for the internal contradictions of a text is one of deconstructionism's main concerns. Deconstructionists may not appease a curious mind in search of some novel ideas, a mind which leads to the discovery of an original subject or an innovative explication that results in new meanings; nevertheless, they may revisit a previously studied subject in a new way so as to provide a different perspective for the reader. As such, instead of trying to clothe a text by a certain ideology, the reader celebrates the existence of different ideologies in the text. In this regard, Catherine Belsey's (2002) explanation justifies the significance of this type of reading:

Analysis reveals that at any given moment the categories and laws of the symbolic order are full of contradictions, ambiguities, and inconsistencies which function as a source of 
possible change. The role of ideology is to suppress these contradictions in the interests of the preservation of the existing social formation, but their presence ensures that it is always possible, with whatever difficulty, to identify them, to recognize ideology for what it is, and to take an active part in transforming it by producing new meanings (p. 42).

Deconstruction by not focusing on a specific ideology has opened up a new chapter in the realm of theory and criticism. Deconstruction has a tendency to unsettle a language through its rather compulsive "attentiveness" and "disruptive" tendency or, as Derrida calls it, a tendency towards a "de-sedimentation" (Derrida, 1976, p. 10). Such an unprecedented perspective is indispensable to the novel observation in the field of literature and of the artifacts of the past or the present time. It is through this very "disruptive attentiveness", which is one of the crucial characteristics of deconstruction, that the multifarious features of love in The Great Gatsby is studied. Love appears in a free flow of signifiers as opposed to how it is believed to have a transcendental being. As such, a new light is shed upon the nature of love by exploring it within the relationship among Gatsby, Tom, and Daisy and it is proved that love has differential and deferral meaning.

\section{Deconstruction}

Deconstruction is the word most associated with Derrida. He used deconstruction for his way of thinking and dismantling the excessive adherence to one specific idea by learning to consider the aspects of truth that may lie in its opposite sides. It was in 1937 that Derrida published his first major book, of Grammatology. From that time on, "his works have been engaged in the business of transformation and reinvention" (Royle, 2003, p. 105). Derrida in of Grammatology constitutes the ardent belief that an author can always be understood to be saying "more, less, or something other than what he [or she] would mean" (1976, p. 158). Derrida tries to render all our familiar and preconceived notions, structures and presuppositions unfamiliar by considering it anew.
Accordingly, some points are to be buttressed for while having a deconstructive purpose to provide a brighter view on this issue. First, our reading will not be a form of hermeneutic interpretation of the text's inherent meaning(s). Rather, it reveals that hermeneutic is itself rooted in a metaphysical desire for fixation of meaning which is reductionist in nature despite its whim to attribute an exalted position to the interpreter himself as the generator of meaning; hermeneutics is a quest for meaning, or, at least, it implies the possibility of reaching unified meanings. As we read in Peter Childs' and Roger Fowler's Routledge Dictionary of Literary Terms (2006):

(Hermeneutics) comprises the general theory and practice of interpretation ... Much as these hermeneuts differ, they do share an allegiance to universality, and to a common human nature which suggests a measure of co-operation and of shared discourse in the interpretive dialogue. Hermeneutic objects may differ, but they are credited as truths which await illumination (p. 103 and 105).

Unlike hermeneutics, which tries to theorize a system of interpretation, deconstruction emphasizes the elusive nature of any such systems; it reveals the metaphysical structure of the hermeneutic quest for meaning and/or knowledge so as to defy the epistemological universalism which takes the subjectivity of the interpreter as unified and transcendent. Deconstruction reveals that the subject and his perceiving consciousness cannot stand outside the text's boundaries. Andy Mousley (2000) observes:

If language, within structuralism, tends to be regarded as an impersonal system, then language, for many poststructuralists, is the very site of human subjectivity. Language, after all, makes it possible to say 'I', it allows us to locate ourselves as subjects (p. 75).

Being located in language, subjectivity becomes as unfixed as the meaning of a sign is because language works by difference an 
by permanent deferral of meaning. As Mousley (2000) maintains, "if language enables or promises subjectivity, then it also postpones it, for we are constantly being dislocated and unsettled by language due to its inherent instability" (p. 75). A subject is not outside the text superimposing its presence to the text under his/her observation. On the contrary, it is a part of the totality of the text, it "is an elusive signifier, which is never fully present to itself" (p. 100). Eventually, one cannot read more into the text, more than what it contains as some of the hermeneutists allege. Quite the reverse, it is the text that exceeds the reader's/interpreter's power of understanding and overflows his perception .

One may look for the solid structures which lead to fixed meanings in an act of interpretation as do the hermeneutists and in doing so; he/she has to suppress a meaning or some meanings to foreground a specific one. Nonetheless, a deconstructive reader will release the text from the burden of such a suppression/suspension. He/she will reveal the reasons why the text cannot be tamed into an epistemic site of meaning.

It never alerts to the fact that there is no meaning in a text. Quite the reverse, it indicates that the text is a hoard of innumerable meanings. As such, all acts of interpretation find a reductive nature and hence betray the openness of the text itself. That is why Derrida emphasizes that "there is nothing outside the text". All acts of interpretation are like cropping a part of an image and omitting the other parts which could otherwise offer a more complete picture. Hence, a signifier in order to mean or to have a signified has to be taken off the natural flow of signification.

Meaning comes through the fixation of the signified by arresting the free flow of signification. However, every signified is a signifier to which is attached a number of other signifieds which are themselves more signifiers for more signifieds; the chain goes on and on to the extent that one may admit that there is no signified at all and eventually no meaning in its true sense. The only thing that remains is the signifier which leads to the other signifiers that, in turn, lead to other more signifiers.

Meaning exists as much as a text is verified for the signifier. Nonetheless, since contexts cannot be saturated with meaning, meaning get illusively naturalized through the structure of its context. "'No meaning can be determined out of context," argues Nicolas Royle (2003), "but no context permits saturation': this is what Derrida's texts keep affirming, while always affirming it differently" (p. 66).

In this regard, Words/signs find meaning only when one arrests meaning by cutting the chain of signification/differentiation. Consequently, the meaning of a sign is always on the move and is yet to come unless we accept the metaphysics of presence, the idea that the meaning of a sign is presented to us through the one-to-one relationship between the signifier and signified and with the interference of interpretation and/or signification to discover this decidable and fixed relationship. In this regard, Catherine Belsey (2002) affirms, "meaning is no longer seizable, a pure intelligibility accessible to our grasp" (p.136). She emphasizes the undecidability of meaning by arguing that:

Deferred, as well as differed, pushed out of reach, meaning becomes undecidable. Thus we can no longer understand the signifier to be preceded by an anterior truth, a meaning, the presence of a signified whose existence ultimately necessitates a transcendental signified (God, nature, reason) to which all truths can be referred (p. 136).

Thus, signifieds and meanings are part of our metaphysical humanism and essentialism, which, as we have already emphasized, are structures in the same symbolic order as language is. The human mind is symbolic and is structured linguistically. As such, Derrida's innovative notion radically "alters the bases on which we might think about thinking, consciousness, presence, being, humanity, 
animality, divinity, identity, intention, decision, responsibility, justice, friendship, desire, memory, death and language, as well as about so many discourses or practices" (Royle, 2003, p. 144).

\section{Deconstructive Reading of Love}

Trying to sketch a status for love can be exhausting as there can always be the question of what is love. The question is always durable and extended in time. There is historicity about the question which makes it always temporally aloof from its answers. Therefore, the answer is always in the status of yet to come. R. S. White (2001) does as much to leave the question "what is this thing called love?" White expostulates:

that we find ourselves circling around an absent center of meaning, an evacuation. To the very pertinent and honest question which might be asked of the mature by the young, why do you not offer us reliable advice about love and desire, since our love-choices will affect us for the rest of our lives? The only answer can be 'Because we do not know what they are (p. 5).

This is in accord with the multiplicity of love's appearance in different contexts changing colors like a chameleon. Irving Singer (2009) has listed some kinds of love that we habitually speak of:

Love of self, of mankind, of nature, of God, of mother and father, of children, of tribe and nation, of sweetheart or spouse or sexual idol, of material possession, of food or drink, of action and repose, of sports, of hobbies or engrossing pursuit, of justice, of science, of truth, of beauty, and so on endlessly. Each variety of love, involving it special object, has its own phenomenology, its own special iridescence within the spectrum that delimits human experience (qtd in Nordland, 2007, p. 21).

As Singer shows, love is various and refers to a range of different human experiences. Plato in his Symposium also refers to the ambiguity concerning the idea of love when Pausanias retorts to Phaedrus's injunction to praise love: "If love were a single being, it would be fine, but as it is, there isn't just one of him. And since there isn't, it would be more correct to say first which particular love we ought to praise" (Cobb, 1993, p. 21). Derrida's argument that love is always divided between the love of who and love of what testifies to the divided nature of love's identity. He asserts:

the history of love, the heart of love, is divided between the love of who and the love of what... I speak of it abstractly, but I think that whoever starts to love, is in love, or stops loving, is caught between this division of the who and the what. One wants to be true to someone-singularly, irreplaceably-and one perceives that this someone isn't $x$ or $y$. They didn't have the qualities, properties, the images that I thought I loved. So fidelity is threatened by the difference between the who and the what (Youtube.com).

Derrida's unprecedented view of love is based upon his idea of "a decentring of the human subject, a decentring of institutions, and a decentring of the logos" (1973, p. 15). Upon closer reading, one can notice the importance of decentering the logos which has indeed become Derrida's primary reason of the whole idea of Deconstruction: "The first step for me, in the approach to what I proposed to call deconstruction, was a putting into question of the authority of linguistics, of logocentrism" (p. 65). Julian Wolfreys (1998) summarize the Derridean notion of logocenterism as follows:

Logocentrism ... brings together two ideas: that of the logos, the Greek term for the Word or Truth (as an unquestionable and desired value, i. e., the Word of God); and center, the concept of a central or originary point, a moment of absolute beginning or origin from which everything springs and around which all ideas circulate or to which they refer (p. 198).

Derrida is not following the path of logos as the whole history of Western philosophy did. $\mathrm{He}$ is against the changing of logos as each 
philosopher has done by substituting one originary point with another instead he aims at the free play of meaning. Likewise, the nature of love can be subjected to his radical view. Transcending love beyond time and space sets it in the realm of ideas, in the realm that is eternal and outlives man and his existence. How can love be eternal if it resides in a man? It has to precede and exceed man's existence in order to be eternal and unchanging. As such, it should reside in the world beyond the material changeability. It resides in the immutable world of immortals. This way of looking at the identity of things or beings, as Barry Stocker (2006) affirms, is rooted in Logocentrism. "Logocenterism in Derrida," he avers, refers to the philosophical tendency to find truth in the presentation of Being, Sprit, Consciousness, History across a philosophical system to any idea, mode of experience, emphasized in a philosophical system" (p. 52). Accordingly, Plato, Descartes, Hegel, and J. L. Austin are logocenteric:

Plato is logocenteric because his dialogues claim to reveal truth with reference to dialectical speech; Descartes is logocenteric because he claims to reveal truth in the clear and distinct ideas of our consciousness; Hegel is logocenteric because he claims to truth in absolute spirit. A more empirical philosopher like Austin is still logocenteric, because the truth of language appears in the immediate situation of the utterance of particular statements (p. 52).

All these philosophers ascribe to unity for achieving truth and meaning. Their attempts are to command their minds to the influence of this metaphysics of presence which guarantees the accessibility/presence of meaning, to the metaphysical ideal that meaning as a presence can be possible because the present time is a fixed totality. Ironically enough, present time is always marked with past-ness because time is on the move unless we are able to freeze time and take a moment, a frame of time as a moment, out of it. This transiency and motion is the inherent quality of all things regardless of whether they are abstract or concrete. As
Derrida (1976) argues, "the metaphysics of presence as self-proximity wishes to efface by giving a privileged position to a sort of absolute now, the life of the present, the living present" (p. 309). However, the "absolute now", as mentioned earlier, is only possible if one takes the dynamicity off the beings. Everything is organic as much as it is subject to time. That is, we need to freeze time in order to reach meaning. Derrida repudiates the possibility of such total freezing of the moment by proposing the idea of representation and/or mimesis.

To Derrida, reality lies merely in representation, in signification, hence his famous statement declaration in of Grammatology that, "There is no outside (of the) text" (1976, p. 155). There is the only a signification of truth, not the truth itself. Origin is myth and truth is merely a textual construct which he attempts to deconstruct.

As Christopher Norris (1989) declares:

As for current post-structuralist theory, a good deal hinges on the crucial ambiguity of Derrida's cryptic statement: there is no outside to the text. On the one hand this can be taken to signify a literary formalism pushed to the extreme, a last-ditch retreat from 'reality' into the solipsistic pleasures of textual free play... If reality is structured through and through by the meanings we conventionally assign to it, then the act of suspending those conventions has a pertinence and force beyond the usual bounds of textual interpretation (p. 109).

Love, therefore, cannot belong to a transcendental consciousness if it only exists as pure, intersubjective, and hence communicable form. If the knowledge of love rests on linguistic ability to communicate "meaning", "memory", and "experience", then it follows and has a medium of expression, a language. Every language is based on a structure that makes it a metaphysical because any idea possessing a structure is metaphysical idea. Ideas need to repeat themselves through the structures of their presence, in the architectonics of their 
presence and thus to exist in the network of linguistic communication. "In referring to an architectonic," Barry Stocker (2006) argues, "Derrida also cast doubt on this model of knowledge, which appears in Foucault's earlier work, by pointing out the instability of any structure to which we might try to reduce knowledge" (p. 107). The structure cannot be transcendental and unchanging. They are on the move through being subject to the iterability of the sign. Signs have to be repeated in order to signify. All structures are meaningful as long as they are iterable. Derrida (1973) detects the primordially repetitive structure of the sign when he writes:

By reason of the primordially repetitive structure of signs in general, there is every likelihood that "effective" language is just as imaginary as imaginary speech and that imaginary speech is just as effective as effective speech. In both expression and indicative communication the difference between reality and representation, between the vertical and imaginary, and between simple presence and repetition has already begun to wear away (p. 51).

What we know as the so-called love that has been named for us throughout the history (historicity of love) and given that name, that transcendental structure of the name, to anything, to any feeling that resembles that historically repeated idea can never be deemed as a transcendental idea and should be studied through a different perspective by decentering it from its long-standing logos and putting it forward as a dynamic concept with a situational moment.

\section{Deconstructive Reading of the Notion of Love in The Great Gatsby}

Kemberly Hearne in a short note on The Great Gatsby refers to the contradictory nature of the American dream. He extrapolates that Fitzgerald has concisely noticed American dream's contradictory inherent features and worked it through in The Great Gatsby:

It is through the language itself, and the recurrent romantic imagery, that Fitzgerald offers up his critique and presents the dream for what it truly is: a mirage that entices us to keep moving forward even as we are ceaselessly borne back into the past (2010, p. 189)

Of all the writers of the time, the writer that most clearly explained the ambiguous nature of the American dream was Fitzgerald. To this end, he recruited the elusive nature of love into his service of harsh criticism to make everybody see the mirage behind the notion of love. In this regard, of central importance to this novel is the divided notion of love between the characters of this novel. It is worthy of note that love should not be deemed as a transcendental notion that exists by itself. Indeed, deconstructionists actually criticize the mentality that sees the world, the people or systems in it as an oppositional contrast. As such, Derrida poses the idea of différance. In the last chapter of Speech and Phenomena, he defines différance as a concept "to be conceived prior to the separation between deferring as delay and differing as to the active work of difference" (1973, p. 88). Consisted of this view, love is not an originary being; on the contrary, it exists as long as it is differentiated from its others which are the product of the oppositional structure of language.

Love in The Great Gatsby can hardly be taken as given because as a signifier it has to suspend its evanescent fluidity in order to identify a solid meaning. It is set in an undecidable context of significance implying a plethora of varying and sometimes contradictory meanings such as emotion, affection, passion, self-indulgence, power, honor, pleasure, conjugation, oneness, etc., and quite paradoxically the list can grow infinitely as long as definite meanings are sought. The diversity of meaning is due to the evanescent nature of the signs, or due to différance (to use Jacque Derrida's pun). As we read in an essay on Derrida's deconstruction in Internet Encyclopedia of Philosophy:

The widespread conviction that the sign 
literally represents something, which even if not actually present, could be potentially present, is rendered impossible by archwriting, which insists that signs always refer to yet more signs ad infinitum, and that there is no ultimate referent or foundation (Reynolds, n.d.)

In considering the diverse meaning of love in The Great Gatsby, one should refer to the relation among three characters including Gatsby, Tom and Daisy within the novel. The triangular relationship among Gatsby, Tom, and Daisy are deemed to show the impossibility of the existence of transcendental love and prove the differential and deferral meaning of love. Daisy's relationship with Tom and Gatsby begins in a sequence. First, Daisy feels in love with Gatsby and decides to devote herself thoroughly to him, however, Gatsby's return from the war is delayed and Daisy is forced to marry someone else. At first, she mounts stiff resistance to this marriage proposal to the extent that in her wedding day, she decides to go back on her decision to marry Tom and ruins everything:

She groped around in a waste-basket she had with her on the bed and pulled out the string of pearls. Take them downstairs and give them back to whoever they belong to. Tell them all Daisy's changed her mine. Say Daisy's changed her mine!' (Fitzgerald, 1925, p. 82).

By any happening, Daisy marries Tom. And after a while, Jordan Baker, Daisy's friend, evokes a memory of Daisy while she was having gone on a trip with Tom:

I saw them in Santa Barbara when they came back and I thought I'd never seen a girl so mad about her husband. If he left the room for a minute she'd look around uneasily and say 'Where's Tom gone?' and wear the most abstracted expression until she saw him coming in the door (p. 83).

Once Daisy used to be in love with Gatsby; now she finds her true love in Tom. Such a radical change in the Daisy's tendency in love denies the possibility of the transcendental love and puts love in the context of difference and away from the singularity of one person. Derrida mentions that the act of loving of someone cannot be solely limited to the singularity of that person whereas the attributes of that person also play a major role in loving him/her. As such, Derrida asserts that "One is attracted because the other is like this or like that inversely, love is disappointed and dies when one comes to realize the other person doesn't merit our love" (Youtube). Hence, Tom's richness plays the difference here in compelling Daisy to love him. Nonetheless, Gatsby's return after five years while he is richer than Tom puts Daisy in another same situation. Expectedly, Daisy switches to Gatsby. This change of view is best shown when Gatsby takes Daisy home to show her his house and properties in it:

He took out a pile of shirts and began throwing them, one by one before us, shirts of sheer linen and thick silk and fine flannel which lost their folds as they fell and covered the table in many-colored disarray. ... Suddenly with a strained sound, Daisy bent her head into the shirts and began to cry stormily. They're such beautiful shirts, she sobbed, her voice muffled in the thick folds. It makes me sad because I've never seen suchsuch beautiful shirts before (Fitzgerald, 1925, p. 99).

Approaching the novel differently, it appears that the story is based on the failure of language. The origin of failure is the radical failure of language which begins in nothing. Language fails to signify what it wishes to represent, to put in more precisely; the signifiers fail to reach the signified. While Gatsby, Tom, Daisy and others are gathered in a hotel. Daisy remembers her wedding in the middle of June when a man fainted due to the hot weather. Afterwards, Tom begins to introduce the man who fainted in the wedding day as follows: "'A man named Biloxi. 'Blocks' Biloxi, and he made boxes-that's a fact-and he was from Biloxi, Tennessee" ( $p$. 136). Suddenly, everybody begins telling something about Biloxi. Jordan mentions that 
'"They carried him into my house,' appended Jordan, 'because we lived just two doors from the church. And he stayed three weeks, until Daddy told him he had to get out .The day after he left Daddy died" (p. 136). Then Nick adds "I used to know a Bill Biloxi from Memphis, I remarked" (p.136). Later, Tom continues like this "That was his cousin. I knew his whole family history before he left. He gave me an aluminum putter that I use today" (p. 136). And when Tom is confronted by Jordan's question that from where did you know him? He answers; "'Biloxi?' He concentrated with an effort. 'I didn't know him. He was a friend of Daisy's" (p. 136). At last, Daisy responds "He was not, she denied. 'I'd never seen him before" (p. 136). As it is obvious, a number of signifiers are presented without even clarifying the signified at all. Even these signifiers have caused more confusion and bewilderment and it is best displayed when Nick comments about Biloxi in this way, "Tom and I looked at each other blankly.'BilOxi?"' (p. 137).

As it is shown, one signified is becoming the signifier for another signified and even it never ends in a final conclusion whereas the sequence of these signifiers and signified makes the situation more difficult to comprehend. The verification of signifier to settle on a fixed signified due to the free flow of signifiers is impossible. As such, meaning is not siezeable and is permanently deferred. Such disorientation of signifiers is presented by Fitzgerald just before Gatsby's sudden movement towards challenging Tom on Daisy's love. The divided nature of love among Gatsby, Daisy and Tom is the most prominent example of disoriented signifiers without fixing and determining the signified. When Gatsby seems to doubt the possibility of Daisy's unified love toward himself, he raises his doubt to Nick by saying: "Her (Daisy) voice is full of money" (p.128). His doubt is mounted up to the point that he cannot control himself and challenges Tom on Daisy's love:

'Your wife doesn't love you,' said Gatsby. 'She's never loved you. She loves me .'You must be crazy!' exclaimed Tom automatically. Gatsby sprang to his feet, vivid with excitement. 'She never loved you, do you hear?' he cried. 'She only married you because I was poor and she was tired of waiting for me. It was a terrible mistake, but in her heart she never loved anyone except me!' (p. 139).

Afterward, Gatsby seeks Daisy's feedback to this situation but he is confused by Daisy's response as she tries to evade answering the question of choosing between Tom and Gatsby because in each moment he really loved each of them. Therefore, she responds in this way: "Oh, you want too much!' she cried to Gatsby. 'I love you now-isn't that enough? I can't help what's past" (p. 141). Derrida believed that a moment in the present time is always marked with the trace of past unless one is able to freeze the time and as it is impossible to cut a moment in the train of time, the absolute now will never occur. Regarding the concept of differance, he clarifies this point in this respect:

Difference is what makes the movement of signification possible only if each so-called 'present' element, each element appearing on the scene of presence, is related to something other than itself, thereby keeping within itself the mark of a past element, and already letting itself be vitiated by the mark of its relation to the future element, this trace being related no less to what is called the future than to what is called the past, and constituting what is called the present by means of this very relation to what it is not, to what it absolutely is not: that is, not even to a past or a future as a modified present (Derrida, 1973, p.142).

Gatsby's central puzzle is his confusing moment about his present time and the past time. He wants to repeat the past in the present time; however, the present time being related to the past and future can never be dragged out and separated from the past time as it always carries with it a trace of past time. At a moment in the novel, Gatsby claims to be able to repeat the past: "'Can't repeat 
the past?' he cried incredulously. 'Why of course you can!"' (Fitzgerald, 1925, p. 118). Such bewilderment eludes Gatsby to the end. Though he admits the impossibility of this action, still he cannot believe it and when he is talking to Nick about Daisy's feeling toward Tom, he says: "Of course she might have loved him, just for a minute, when they were first married-and loved me more even then, do you see?" (p. 162).

Although the movement of the action of the novel after the love test scene should naturally be toward the signified of the words uttered by Daisy, the actualization is caught in a permanent deferral and difference because Daisy proves to be completely at odds with what she had claimed and was just incapable of concertizing what she really intended by not articulating her true love to Gatsby. This actually conforms to the Derridean idea of arrivant, that the event of love is and will be always on the state of deferral and delay, an arrivant which never completely arrives. "The arrivant", Derrida writes:

Must be absolutely other, an other that expects not to be expecting, that I'm waiting for, whose expectation without what in philosophy is called a horizon of expectation, when a certain knowledge still anticipates and amortizes in advance. If I am sure there is going to be an event, this will not be an event (Lucy, 2004, p. 6).

Gatsby in challenging Tom on Daisy's love foregrounds this deferral relationship by demanding Daisy to express her love. The love test, however, launches a problem that can never be resolved unless the very idea of love is set in materiality that can defy the metaphysics of presence on the part of the language or any system of signification that is employed to present it. This is an impossibility which is the very condition of love's ontological existence. Daisy is an image of idealism, transcendence, and the logocentric truth in the eye of Gatsby. He assumes that he can earn Daisy's ideal love once for all, nonetheless, he can never gain her truly.
Deconstruction is against all generalizations, metaphysical, reductionisms, and aphorisms. It reveals what is hidden, what we naturally tend to overlook in order to communicate; it aims at betraying, in Derrida's words, "the illusion of unity or univocity" (Wolfreys, 1998, p. 60). Within the context of deconstructionists, the notion of love also follows the same role; it can never be expressed as a unified concept toward a singular person whereas it is a divided notion put in the context of difference. Gatsby's imagination has built an imaginary world for him in which he searches for some predetermined truth and reality. $\mathrm{He}$ is unaware of the fact that the true nature of reality is a mere construction by which meaning is conventionally construed. Reality indeed is a sort of representation at a moment which cannot be repeated at any other moment. And if one substitutes the usual bonds behind the formation of reality, the reality itself will take another shape and proves its illusive nature. At a moment in the novel, Nick clearly shows Gatsby's notion of reality along these lines:

Each night he added to the pattern of his fancies until drowsiness closed down upon some vivid scene with an oblivious embrace. For a while these reveries provided an outlet for his imagination; they were a satisfactory hint of the unreality of reality, a promise that the rock of the world was founded securely on a fairy's wing (Fitzgerald, 1925, p. 102).

With the help of deconstruction, Gatsby's failure in achieving his true love is best expressed. In this regard, Gatsby's long and careful observation of green light at the end of Daisy's house accords with his belief in transcendental love on which he could never live. Most probably, Nick as the narrator of the novel ends such a way: "Gatsby believed in the green light, the organstic future that year by year recedes before us" (p. 193). Nick's ending best support the argument of deconstructionist about its anti-centering nature. Everything is organic as much as it is subjected to time. One can never reach an absolute now without freezing the time. Therefore, the concept of truth is just 
signified and is a mere construction by the human mind which Derrida has tried to deconstruct. Derrida has persistently emphasized that "there is nothing outside the text". In this respect, Gatsby's repetitive observation of the green light can never be more than a mere illusion of Daisy's transcendental love. Everything is situated within the text and the meaning of each sign is unfixed and iterable. In our discussion, the iterability of the concept of love examined through Gatsby's relation with Daisy.

\section{Conclusion}

By a brief review of philosophical history, a logical conclusion can be drawn that each philosopher has tried to bring up his notion of thought even if it is at the expense of neglecting the previously established notion of thought. Nevertheless, Derrida is the first one who claims not to discuss a new idea, yet examining the previous ideas in an entirely new perspective. Unlike the previous system of thoughts which aimed at reaching a unified purpose and revealing the metaphysical structure of meaning, deconstructionists defy the concept of unified meaning. In this respect, human subjectivity as a site of meaning is located within the system of language. As such, the meaning of a sign works through the concept of differance. More importantly, the meaning is always limited to text; in other words, nothing outside the text ever exists or has the ability to determine the meaning, accordingly, the notion of metaphysics is totally rejected by the deconstructionists. Furthermore, the deconstructionists establish the fact that a text is not directed toward one specific meaning whereas it is filled with innumerable meanings and what is commonly implied as meaning is only fixation of the free flow of signifiers. Consequently, the meaning is always on the move and not fixed.

In this respect, love as a human experience is considered by Derrida while being based upon his idea of decentering and anti-metaphysics. Transcending love beyond time and space is not acceptable in the Derridean notion of deconstruction. As we are always within the train of time, everything is organic and mutable. In this regard, love as a communicable sign is confined to the rules of iterability and in the case of The Great Gatsby; it is presented as a signifier soaked in the evanescent fluidity and extremely far away from the possibility of having a fixed meaning. It implies a hoard of contradictory meaning for each person. Approaching the concept of love with this regard shows the reason behind Gatsby's failure in achieving Daisy's love. Gatsby's main concern is to repeat the past and fully gain Daisy's love. Nevertheless, present, past and future times are always interrelated and never exist without the trace of others. Thus, he can never achieve an absolute moment or Daisy's absolute love. 


\section{References}

Belsey, C. (2002). Critical Practice, London and New York: Routledge.

Brooks, C. (1973). American literature: The Makers and the Making. Book D, 1914 to the Present. New York: St. Martin's Press.

Childs, P., \& Roger F. (2006). The Routledge Dictionary of Literary Terms. London and New York: Routledge.

Cobb, W. S., (Trans.). (1993). The Symposium and the Phaedrus: Plato's Erotic Dialogues. New York: State University of New York Press.

Derrida (1976). Of Grammatology, Trans. Gayatri Chakravorty Spivak. Baltimore, MID: John Hopkins Press.

Derrida, J. (1973). Speech and Phenomena. (D. B. Allison, Trans.). Evanston, IL: Northwestern University Press.

Derrida, J. (Speaker). (2011, Jan. 26). On Love and Being [Video file]. Retrieved from http://www.youtube.com/watch?v=dj1BuNmhjAY.

Fitzgerald, F. C. (1978). The Notebooks of F. Scott Fitzgerald (M. J. Bruccoli, Ed.). New York and London: Harcourt Brace Jovanovich.

Fitzgerald, F. C. (1925). The Great Gatsby. New York: Scribner's.

Ghasemi. P., \& Tiur. M. (2009) The Promise and Failure of the American Dream in Scott Fitzgerald's Fiction, Kata Journal, Vol. 11, No 2, pp.117-127.

Ghasemi. P., \& Tiur. M. (2009) Scott Fitzgerald, the Man and his Heroes: The Lost Generation, Research on Foreign Languages Journal of Faculty of Letters and Humanities, Vol. 51, No 206. pp. 33-43.

Hearne, K. (2010). Fitzgerald's Rendering of a Dream. Vo. 68, Issue 3. pp. 189-194.

Reynolds, J. Internet Encyclopedia of Philosophy: A peer-Reviewed Academic Resource. "Jacques Derrida." http://www.iep.utm.edu/derrida/.

Keshmiri. F. (June 2016) The Disillusionment of F. Scott Fitzgerald's Dreams and Ideals in The Great Gatsby, Theory and Practice in Language Studies, Vol. 6, No. 6, pp. 1295-1299.

Lucy, N. (2004). A Derrida Dictionary. Malden: Blackwell Publishing Ltd.

Mousley, A. (2000). Renaissance Drama and Contemporary Literary Theory. London: MacMillan Press LTD.

Nordlund, M. (2007). Shakespeare and the nature of love: Literature, culture, evolution. Illinois: Northwestern University Press.

Norris, C., (1991). Deconstruction Theory and Practice. Revised Edition. London and New York: Routledge.

Royle, N. (2003). Jacques Derrida. London and New York: Routledge.

Singer, P. N. (2009). The Nature of Love 2: Courtly and Romantic. Cambridge: The MIT Press.

Stocker, B. (2006). Routledge Philosophy Guidebook to Derrida on Deconstruction. London and New York: Routledge.

Streissguth, T. (2007). The Roaring Twenties. New York: Facts On Files Inc. Print.

White, R. S. (Ed.). (2001). Romeo and Juliet: New casebooks. Hampshire and New York: Palgrave.

Wolfreys, J. (1998). Deconstruction: Derrida. London: MacMillan Press Ltd. 
